\title{
The Effect of Different Fire Regimes on Soil Properties in Wet Miombo woodlands of Zambia
}

\author{
Weston Sakala ${ }^{1,2} \quad$ Felix Chileshe $^{1} \quad$ Royd Vinya $^{1}$ \\ 1.School of Natural Resources, Copperbelt University, P.O. Box 21692, Kitwe, Zambia \\ 2.Zambia Forestry College, P/ Bag 1 Mwekera, Kitwe, Zambia
}

\begin{abstract}
Miombo woodlands occur on nutrient poor soils and generally experience a warm-to-hot climate with a dry cold season. Wet miombo areas, which receives more than $1,000 \mathrm{~mm}$ of average annual rainfall, are distinguished from dry miombo areas receiving less than $1,000 \mathrm{~mm}$ of average annual rainfall. Wet miombo woodland occurs over much of eastern Angola, northern Zambia, south western Tanzania and central Malawi in areas receiving more than $1000 \mathrm{~mm}$ rainfall per year. Canopy height is usually greater than $15 \mathrm{~m}$, reflecting the generally deeper and moister soils which create favourable conditions for growth. The objective of this study was to investigate the effect of different fire regimes on soil properties in wet Miombo woodlands of Zambia. The study was conducted in Mwekera burning plots located in Mwekera National Forest No. 6 on the outskirts of Kitwe City. This study has uncovered some interesting relationships between fire and soil nutrients, soil chemical and physical properties. The complete fire protected treatment had significantly greater soil bulky density, organic soil carbon, phosphorus $(\mathrm{P})$ and nitrogen $(\mathrm{N})$ than other treatments. The late burning treatment had significantly greater soil $\mathrm{pH}$, soil electrical conductivity, Calcium $(\mathrm{Ca})$ and magnesium $(\mathrm{Mg})$ than other treatments; however, a loss of soil organic matter during late burning fires likely resulted in increased bulk density and strength, and decreased water infiltration rates. Late burning fires also significantly increased soil $\mathrm{pH}$, concentrations of extractable calcium, magnesium and carbon although to a lesser degree than early burning. Early burning fires did not lower soil potassium contents or alter soil chemical and physical properties. Our results indicate that despite differences in fire regimes, soil moisture, calcium and magnesium contents were not significantly different between early burning and late burning treatments. The results suggest that fire management did not affect soil moisture, calcium, and magnesium contents.
\end{abstract}

Keywords: burning plots, fire regimes, soil properties, wet miombo woodlands

DOI: $10.7176 / \mathrm{JRDM} / 66-04$

Publication date:June 30th 2020

\section{Introduction}

Miombo woodland soils are typically acidic, have low cation exchange capacities (CEC), and are low in nitrogen, exchangeable cations (total exchangeable bases: TEB) and extractable phosphorus. Land-use practices such as chitemene slash-and-burn agriculture (Araki 1993) may also have a long-term impact on soil properties and need further investigation. Organic matter levels are also generally low, except under densely wooded vegetation. Nevertheless, organic matter contributes substantially to cation exchange capacity in these soils. Furthermore, some nutrient dynamics are more sensitive to fires than others. (Marschner et al., 2008; Thévenot et al., 2010). Soil organic matter (SOM) persistence is rather affected by soil organic carbon (SOC) stabilization in the soil matrix through its interaction and association with soil minerals (Schmidt et al., 2011). The intensity and timing of burning can have further selective impacts on miombo woodlands, affecting and decreasing soil C stocks (Bird et al. 2000).

Fire is therefore, a complex disturbance force, with considerable implications for the dynamics of miombo woodland (Ryan and Williams 2011). The major soil elements and organic carbon stocks is also still poorly understood in terms of depth distribution of stocks in the soil and associated relationships with different fire regimes (Jobbágy \& Jackson, 2000; Parton et al. 1987). Regardless of the potentially significant impact fires has on the major soil elements and carbon stocks of this important vegetation, currently, no research has been done to evaluate the effect of different fire regimes on soil properties in wet Miombo woodlands.

Therefore, the behavior and availability of macronutrients such as $\mathrm{P}, \mathrm{Mg}, \mathrm{K}, \mathrm{S}, \mathrm{Ca}$, and $\mathrm{N}$ with respect to fire is not fully understood, because specific studies are lacking (Certini 2005). However, as time increases after fire, increases in both soil $\mathrm{C}$ and $\mathrm{N}$ through inputs from litterfall and root turnover lead to sequestration of soil $\mathrm{C}$ and N (Johnson and Curtis 2001; Kaye et al. 2010). Unfortunately, little research on fire impacts on soil C and $\mathrm{N}$ has been conducted in sub-Saharan Africa in spite of frequent fires in the region (Archibald et al. 2012). These results suggested that further studies were to be consider to assess the effect of different fire regimes on soil properties. Therefore, this necessitated the need to conduct a research on the effect of different fire regimes on soil properties in order to improve our understanding on the impact of forest fire on soil $\mathrm{C}$ and macro nutrients in sub-Saharan Africa.

Since fire has been used in African landscapes to improve pasture for livestock for thousands of years (e.g. 
Bowman et al. 2009; Archibald et al. 2012). It is therefore important to understand how fire affects the soil properties of this fire prone vegetation.

The objectives of this paper is to assess the impact of different fire regimes on macronutrients, and soil $\mathrm{C}$ and other soil properties by comparing burned areas with unburned areas. We hypothesized that early and late burning fires would significantly decrease forest macro nutrients and soil $\mathrm{C}$ pools but that major soil elements and carbon storage is higher in unburnt sites than in sites that have been burnt. We hypothesized that major soil nutrients and organic carbon differs at different depths and decreases with depth across all treatments. We also hypothesized that early burning fires decrease major soil nutrients and carbon stocks less than late burning fires.

\section{Research Questions:}

How does different fire regimes affect soil properties?

Do fires alter the distribution of major soil elements and organic carbon along different soil depths?

\section{Materials and methods}

The study region is Zambia in Central-Southern Africa in particular Mwekera burning plots (Figure 1). This area was selected purposively because it is the only burning plot in Zambia and besides it is suitable for research because it has adequate access, and sufficient long-term security from human disturbance coupled with high level of tree diversity. The study area was chosen on the basis that it falls within the wet miombo woodlands which are characterized by annual precipitation ranging between 1300 and $1800 \mathrm{~mm}$. The soil samples were collected from sample plots that were demarcated within the Mwekera burning plots. The treatments applicable to the plots were early and late burning done in June and October respectively. The burning treatments were repeated in the same plots annually. Fieldwork was carried out between February 2018 and March 2018 during the middle of the rain season. This time was used since it was easy for soil sample collection.

\subsection{Study site}

The study was carried out in Mwekera Forest reserve in the outskirts of Kitwe district at the elevation of $1,295 \mathrm{~m}$ above sea level. The forest reserve is about $20 \mathrm{~km}$ South-east away from Kitwe town centre, The burning plots are in Mwekera Forest Reserve (between latitudes $12.75 \mathrm{o}^{\mathrm{C}}$ and $12.867 \mathrm{o}^{\mathrm{C}} \mathrm{S}$ and longitudes $28.267 \mathrm{o}^{\mathrm{C}}$ and $28.500 \mathrm{o}^{\mathrm{C}}$ E ), Kitwe District, on the Copperbelt Province of Zambia. The Mwekera fire experimental burning plots (12.850 $\mathrm{o}^{\mathrm{C}} \mathrm{S}, 28.35 \mathrm{o}^{\mathrm{C}} 0 \mathrm{E}$ ) are about $2 \mathrm{~km}$ north-east of the Zambia Forestry College (figure 1).

Burning Plots in Mwekera

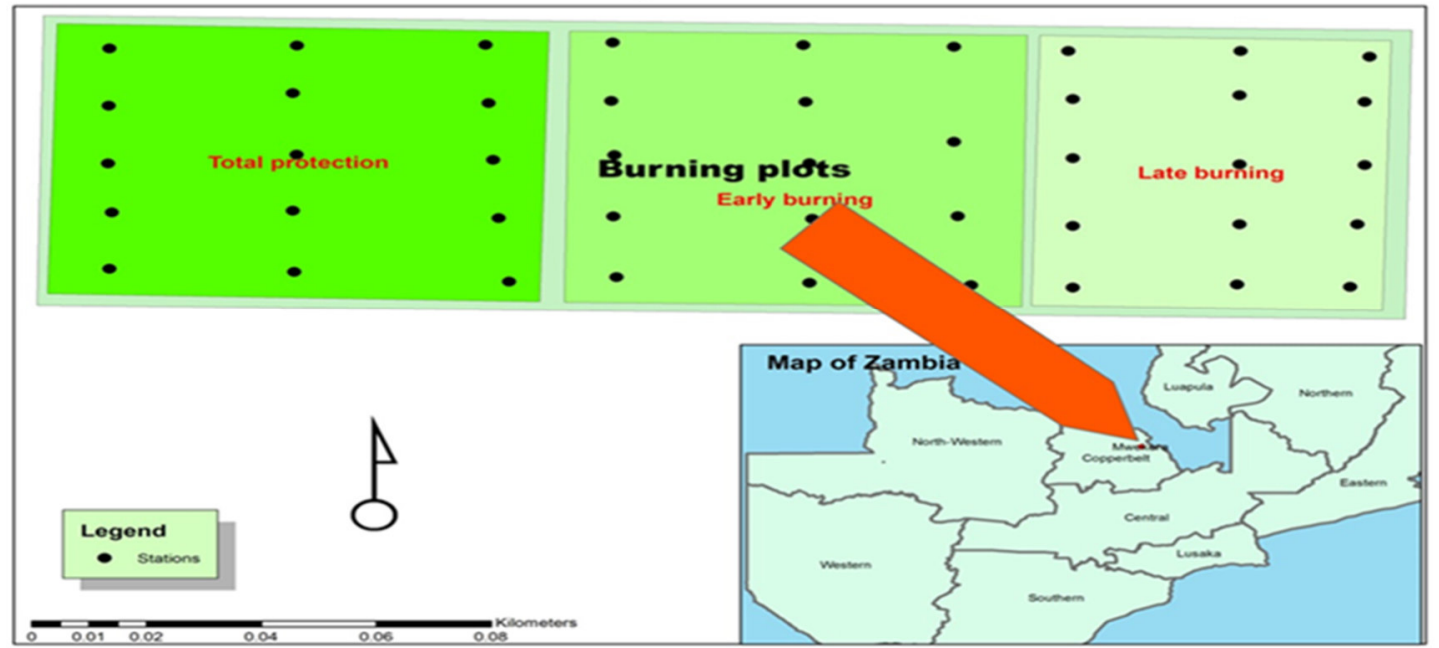

Fig 1: Location map of the study area

Mean annual rainfall at Mwekera fisheries research Centre, $2.5 \mathrm{~km}$ from the plots, for the period 2000-2019 was $1171 \mathrm{~mm}, 95 \%$ of this falling from November to March. However, quarter-degree gridded climatology data for the Mwekera area for the period 1961 to 1990 gave annual rainfall to be $1248.4 \mathrm{~mm}$ while the average temperature was $20.27 \mathrm{o}^{\mathrm{C}}$ (Chidumayo, 1988).

Each plot was assigned to one of the three fire treatments: complete fire protected (FP), early burning (EB) and late burning (LB) with the EB plot located between the other two plots. Each plot is surrounded by a 3-m wide cleared firebreak and a 5-m wide inter-plot strip of old-growth woodland. Immediately beyond the perimeter firebreak the plots are surrounded by old-growth woodland to the north, east and south and by plantation forest to the west. 


\subsection{Collection of soil samples}

Three treatments i.e complete fire protected, early burning and late burning areas were selected that included a chronosequence of fire regime. The first site complete fire protected (CP) had no fire event since 1961, the second site early burning (EB) had an early fire event since 1961, and the third site (LB had a late fire event since 1961. From interviewing local residents, we found that there was an accidental fire in the complete fire protected in 1996. The three sites are $1.5 \mathrm{~m}$ from each other and have dominant vegetation that varied across burned and unburned areas and across sites. Fifteen soil sampling plots were systematically selected in each treatment i.e. burned and unburned sites (3-m distance between plots) that were known to be burned and unburned (i.e. no edge effects).

A soil profile was excavated from 0 to $100-\mathrm{cm}$ depth at each soil sampling plot. Soil was collected with a core sampler (5-cm diameter) from 0-30, 30-60, and 60-100 cm soil depths. The soil samples from the core were used to determine soil bulk density and the samples from the three horizons were used to determine soil conductivity, soil moisture content, soil porosity, soil organic carbon (SOC) and macro nutrients concentration. Bulk density of the forest floor and mineral soil was determined by dividing the oven-dry mass $\left(408^{\circ} \mathrm{C}\right.$ for forest floor, $1058^{\circ} \mathrm{C}$ for mineral soils) by the soil volume (Grossman and Reinsch 2002). Forest floor sub samples were ground to a fine powder. Mineral soil subsamples were sieved $(2 \mathrm{~mm})$ and ground. Forest floor and soil subsamples were analysed for organic carbon (OC) concentration using the Walkley-Black titration method (Walkley and Black 1934; Nelson and Sommers 1996) and for total nitrogen (TN) concentration using the Kjeldahl method (Bremner and Mulvaney 1982).

To determine SOC and macro nutrients pools for 0 to $100 \mathrm{~cm}$ depth, SOC and macro nutrients pools of each sample depth $(0-30,30-60$, and 60-100 cm) were determined and the values were summed.

\section{Statistical analysis}

Soil $\mathrm{pH}$, moisture content, Mehlich-I extractable elements, organic matter content, resin-available $\mathrm{N}$ and $\mathrm{P}$ were analyzed using an ANOVA with repeated measures. The treatment was a fixed effect and block a random effect in each model. Soil properties were log transformed for analyses when not normally distributed, but all values presented in the text were non-transformed. Where a significant time $\times$ treatment interaction was found, variables were analyzed separately by month. Statistically significant differences $(P<0.05)$ were further analyzed with Tukey's HSD multiple comparisons. Square transformed values of bulk density were compared among treatments using an ANOVA with treatment and month as fixed effects and blocks as a random effect, followed by Tukey's HSD multiple comparisons. Log transformed rates of infiltration were compared among treatments using an ANOVA with treatments and repetitions (i.e., each 5-cm increment) as fixed effects and blocks as random effects. For all datasets, the normality of the distribution of the data was first analysed using the Shapiro-Wilk normality test (Shapiro and Wilk 1965). When the standard assumptions of normality were violated, a Mann-Whitney rank sum test (Mann and Whitney 1947) was used. These statistical analyses were conducted using SAS ver. 9.2.

In order to answer the question whether significant differences in major soil elements and organic carbon differs at different depths of the soil and decreases with depth across all treatments, we used a mixed-effects ANOVA (Zar, 2000). Linear regression analysis allowed us to explore the relationship between treatments. We also developed series of general linear models (GLM) to answer the question whether fires alter the distribution of major soil elements and organic carbon along different soil depths (Hofmann and Solbrig, 2003). Data were subjected to logarithmic transformations in order to meet normality and variance homogeneity requirements for both ANOVA and linear regression. All statistical analysis was carried out using R command.

\section{Results}

Analysis of variance on factors whose errors are not normally distributed yielded the following results:-

Table 1: ANOVA

\begin{tabular}{|l|l|l|l|l|l|}
\hline P values & DF & Bulky Density & Solids & $\mathrm{pH}$ & Conductivity \\
\hline Treatment & 2 & 0.865 & 0.8113 & 0.0559 & $* * 0.00626$ \\
\hline Horizons & 2 & $* * 0.015$ & $* * 0.0211$ & 0.0673 & 0.5159 \\
\hline Residuals & 4 & & & & \\
\hline
\end{tabular}




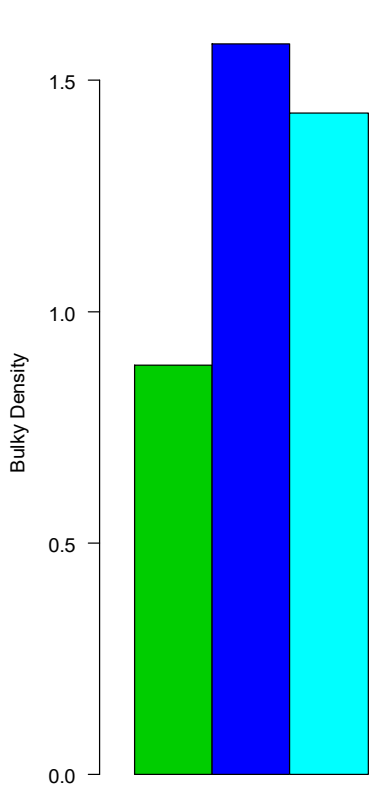

CP
Soil Bulky Density

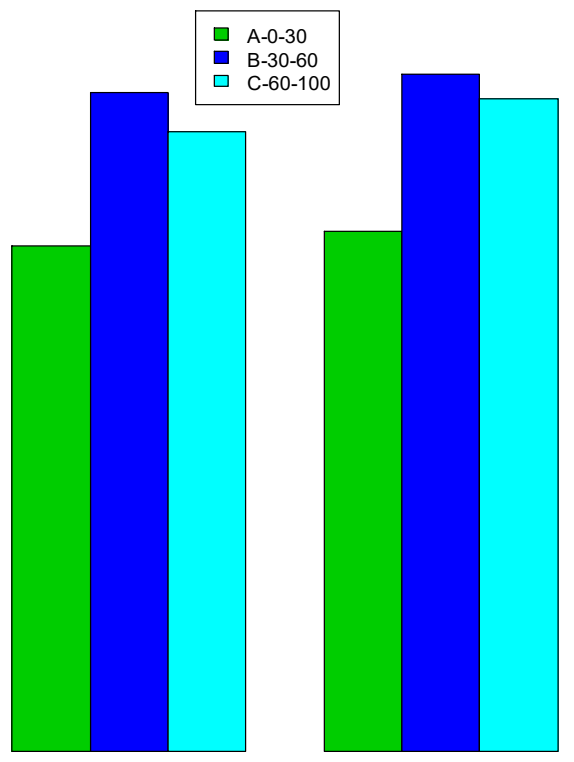

EB

LB

Figure 2: Soil bulky density

Generally, the BD (bulk density) of mineral soils range from 1.0 to $1.8 \mathrm{~g} / \mathrm{cm}^{3}$. Bulk density is an indicator of soil compaction. It is calculated as the dry weight of soil divided by its volume. This volume includes the volume of soil particles and the volume of pores among soil particles. Soil BD and porosity (the number of pore spaces) reflects the size, shape and arrangement of particles and voids (soil structure). According to figure 2 and table 1 there is no significant $(\mathrm{P}>0.05)$ difference in soil bulky density between treatments. However, there is a significant difference in soil bulky density between horizons $(\mathrm{P}<0.05)$. There was more soil bulky density in the complete fire protected treatment in the first horizon of $0-30 \mathrm{~cm}$.

pH

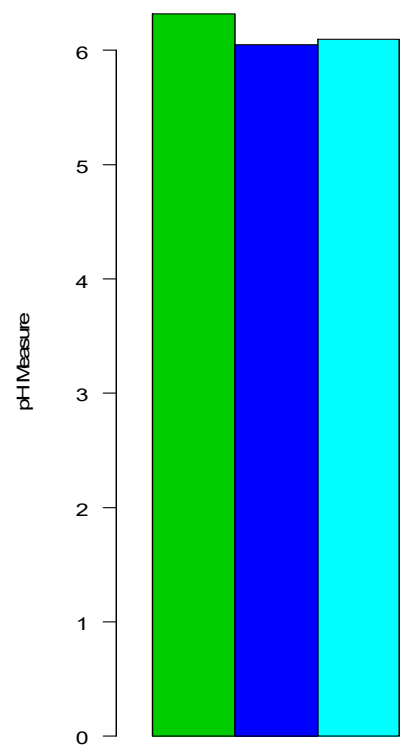

CP

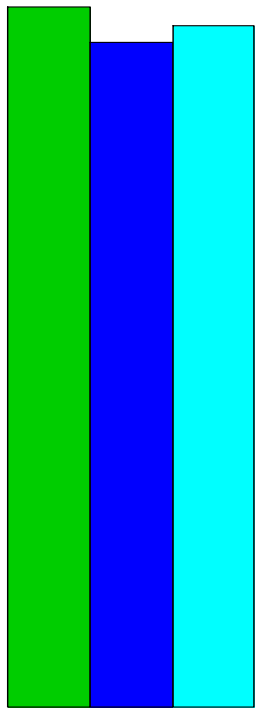

EB

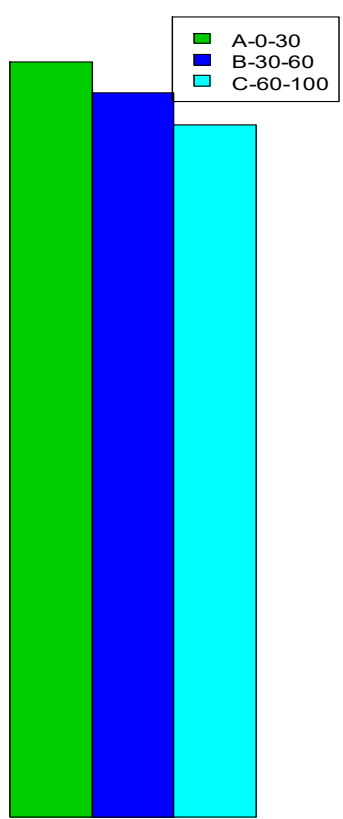

LB

Figure 3: soil pH

Soil $\mathrm{pH}$ is a measure of the quantity of hydrogen present in the soil. As the amount of hydrogen in the soil increases, the soil $\mathrm{pH}$ reading decreases, thus becoming more acidic. Hydrogen carries a weak positive electrical charge which enables it to attach to negatively charged sites on the clay and humus particles in the soil that contain most of the nutrients the plants needs to thrive. Therefore, according to figure 3 and table 1 there is no significant 
$(\mathrm{P}>0.05)$ difference in soil $\mathrm{pH}$ between treatments and horizons.

Organic Carbon Content

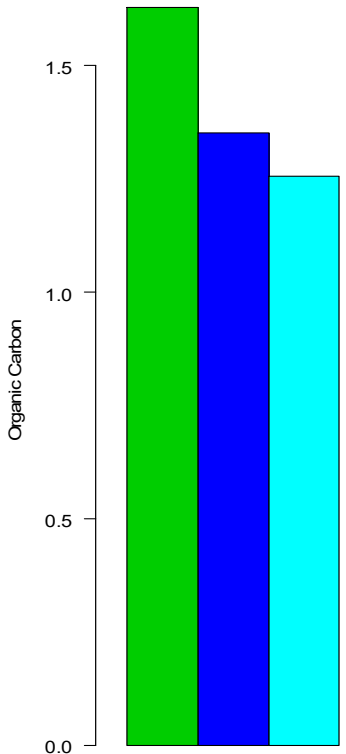

CP

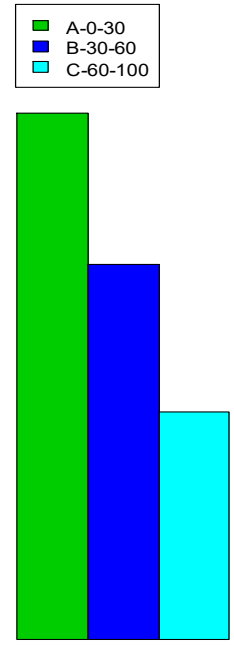

EB

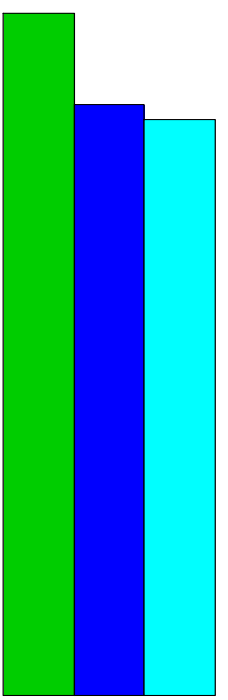

LB

Figure 4: Soil organic carbon

Soil organic carbon is the major component of the soil organic matter. Organic material in the soil is essentially derived from residual plant and animal material, synthesised by microbes and decomposed under the influence of temperature, moisture and ambient soil conditions. Our results in figure 4 show significant $(\mathrm{P}<0.05)$ difference in organic carbon between treatments. There was more total carbon in complete fire protected treatment followed by late burning treatment in the 0-30 horizon. There was less organic carbon in the early burning. However there was no significant $(\mathrm{P}>0.05)$ difference in organic carbon between horizons.

Conductivity

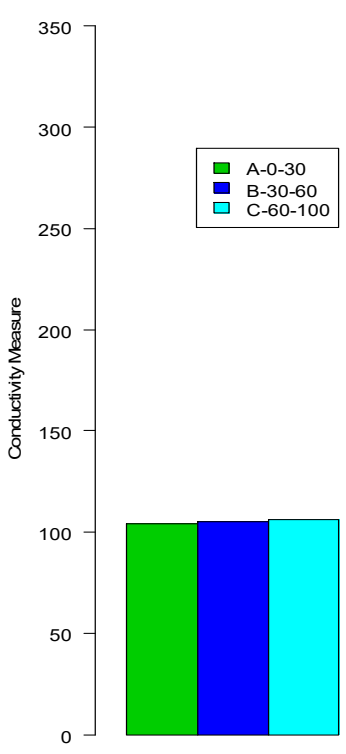

CP

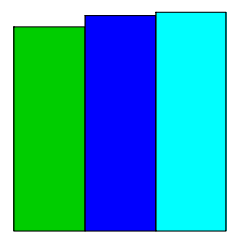

EB

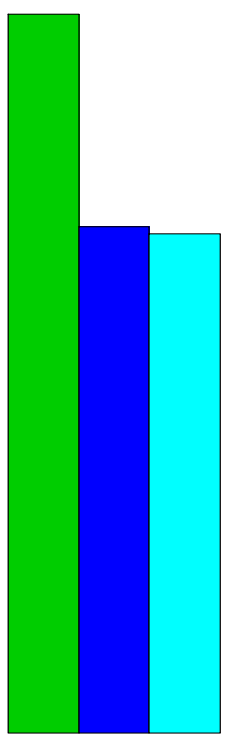

LB

Figure 5: soil electrical conductivity

The soil electrical conductivity varies depending on the amount of moisture held by soil particles. Sands have a low conductivity, silts have a medium conductivity, and clays have a high conductivity. Consequently, soil conductivity correlates strongly to soil particle size and texture. Our results in figure 5 and table 1 show a significant $(\mathrm{P}<0.05)$ difference in soil conductivity between treatments. There was more in the late burning. However, results show no significant $(\mathrm{P}>0.05)$ difference in soil conductivity between horizons. 
Table 2: ANOVA

\begin{tabular}{|c|c|c|c|c|c|c|c|c|c|c|c|}
\hline \multicolumn{12}{|l|}{$P$ values } \\
\hline & DF & Moisture Content & Nitrogen & Total Porosity & Organic Carbon & Organic Matter & Total Carbon & Phosphorous & Potassium & Calcium & Magnesium \\
\hline Treatment & 2 & 0.1007 & $* *_{0.043}$ & 0.8095 & $* * 0.00931$ & $* * 0.00921$ & $* * 0.00768$ & 0.691 & $* * 0.00735$ & $* * 0.001$ & 0.0595 \\
\hline Horizons & 2 & $* * 0.0317$ & 0.0682 & ${ }^{* * 0} 0.0186$ & 0.05561 & 0.05592 & 0.05199 & 0.383 & 0.13229 & 0.577 & 0.6146 \\
\hline Residuals & 4 & & & & & & & & & & \\
\hline
\end{tabular}

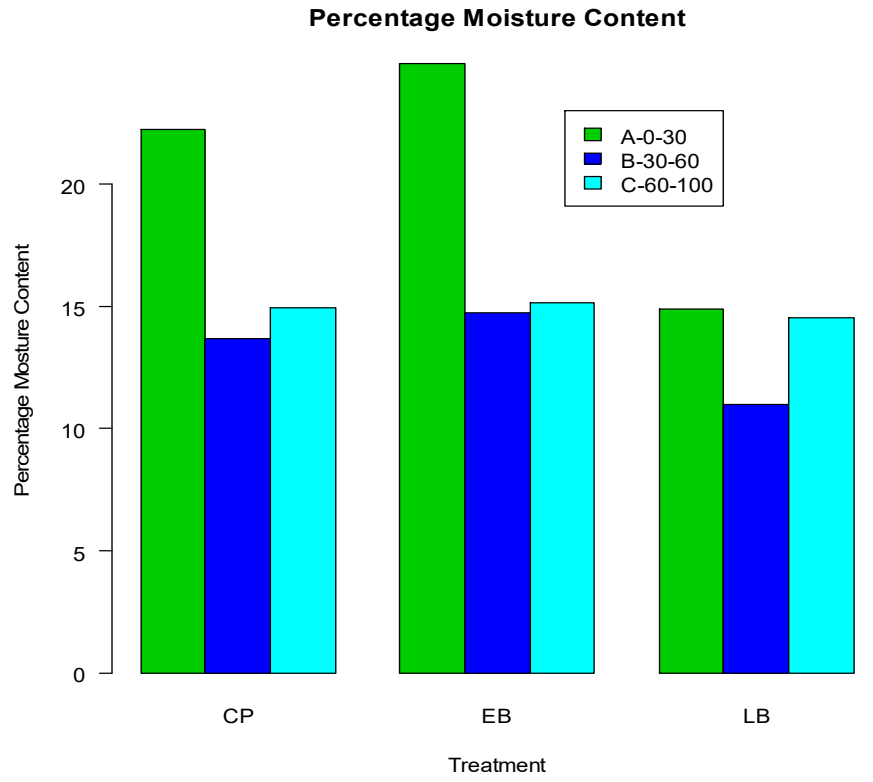

Figure 6: soil moisture content

Soil moisture content refers to the volume of water in a given volume of soil. Soil moisture content is very dependent on soil type. A saturated coarse, sandy soil can hold far less water than a saturated heavy silt clay. According to figure 6 and table 2 the results show no significant $(\mathrm{P}>0.05)$ difference in moisture content between treatments. However the results show a significant difference in moisture content between horizons $(\mathrm{P}<0.05)$. There was more moisture content in the early burning treatment in the first $(0-30 \mathrm{~cm})$ horizon.

\section{Total Porosity}

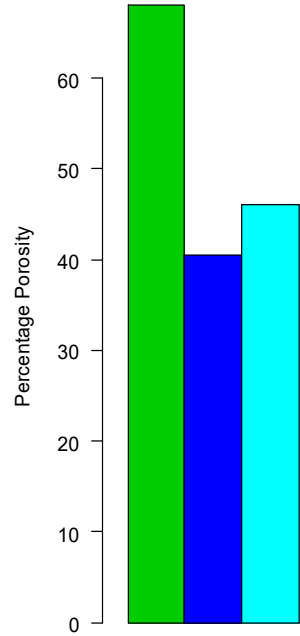

$\mathrm{CP}$

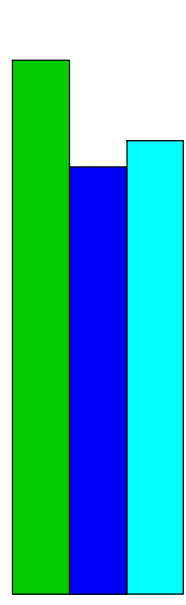

EB

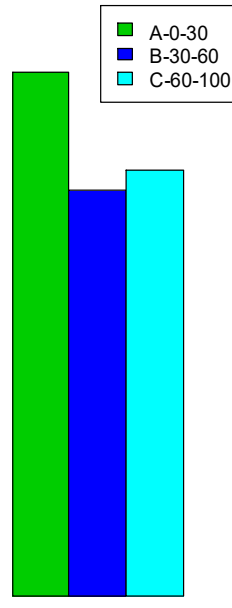

LB

Treatment

Figure 7: Total porosity

The air and water in the soil exist in the pore space in the soil. The size of the pores range from sub microscopic between silt and clay particles to the very large pores visible to the eye which are formed by earthworms and decaying root channels commonly called bio-pores. The results in figure 7 and table 2 show no significant $(\mathrm{P}>0.05)$ difference in total porosity between treatments. However, the results show significant 
difference in total porosity between horizons $(\mathrm{P}<0.05)$. There was more total porosity in the first horizon in complete fire protected treatment.

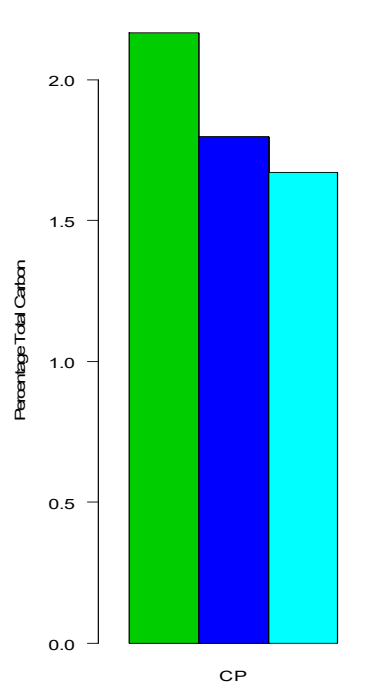

$$
\text { Total Carbon }
$$

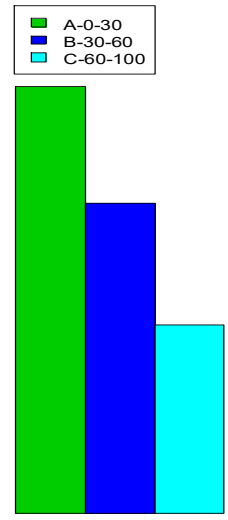

EB

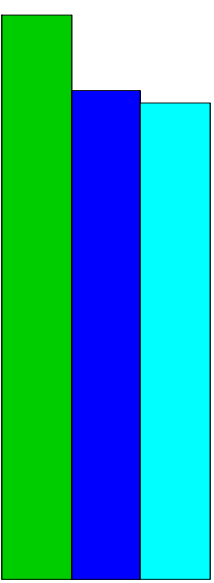

LB

Figure 8: Total carbon

Most total carbon is located near the soil surface. In miombo woodlands approximately $60 \%$ of total carbon is located in the topsoil $(0-10 \mathrm{~cm})$. The results in figure 8 and table 2 show significant $(\mathrm{P}<0.05)$ difference in total carbon between treatments. There was more total carbon in complete fire protected treatment followed by late burning treatment. There was less total carbon in the early burning. However, the results show no significant $(\mathrm{P}>$ 0.05) difference in total carbon between horizons.

On the other hand organic matter makes up just $2-10 \%$ of the soils mass but has a critical role in the physical, chemical and biological function of soils. Carbon is a measureable component of soil organic matter. Organic matter contributes to nutrient turnover and cation exchange capacity, soil structure, moisture retention and availability, degradation of pollutants, greenhouse gas emissions and soil buffering. The results show significant $(\mathrm{P}<0.05)$ difference in organic matter between treatments. There was more organic matter in complete fire protected treatment followed by late burning treatment in the $0-30 \mathrm{~cm}$ horizon. We found no significant $(\mathrm{P}>0.05)$ difference in organic matter between horizons.

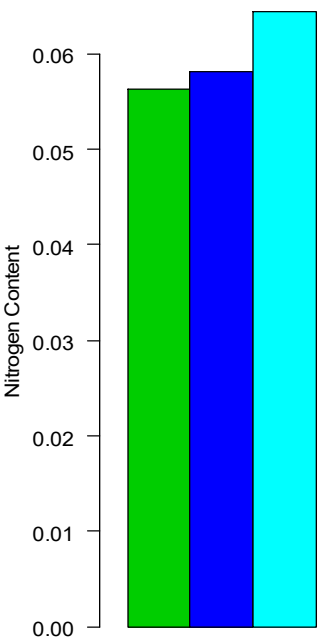

CP

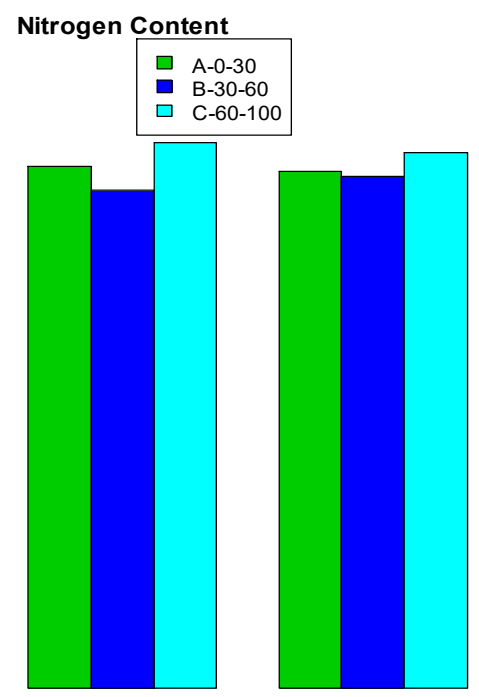

LB

Figure 9: Soil nitrogen content

Plants require more nitrogen $(\mathrm{N})$ than any other nutrient but only a small portion of the nitrogen in soil is available to plants; $98 \%$ of the nitrogen in soil is in organic forms. Most forms of organic nitrogen cannot be taken up by plants, with the exception of some small organic molecules. The results in figure 9 and table 2 show a significant $(\mathrm{P}<0.05)$ difference in soil nitrogen content among treatments. There was more nitrogen in third 
horizon $(60-100 \mathrm{~cm})$ of the complete fire protected treatment. However, the results show no significant $(\mathrm{P}>0.05)$ difference in soil nitrogen content between horizons.

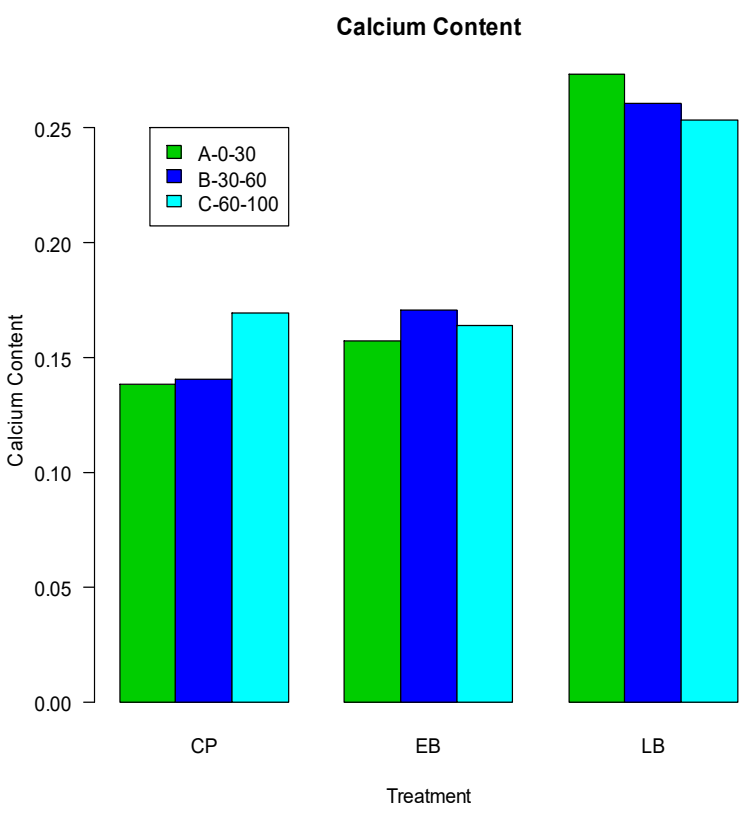

Figure 10: Soil calcium content

Calcium is a plant-essential nutrient that attach to the soil clay and organic matter. The relative proportion of this element, as well as the total amount in the soil, depends mainly on the soil parent material. The results in figure 10 and table 2 show statistically significant $(\mathrm{P}<0.05)$ differences in soil calcium content between treatments. There was more calcium in the late burning treatment. However, the results show no significant $(P>0.05)$ difference in soil calcium content between horizons.

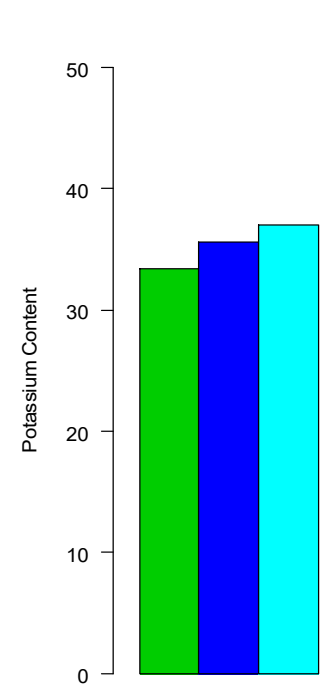

CP
Potassium Content

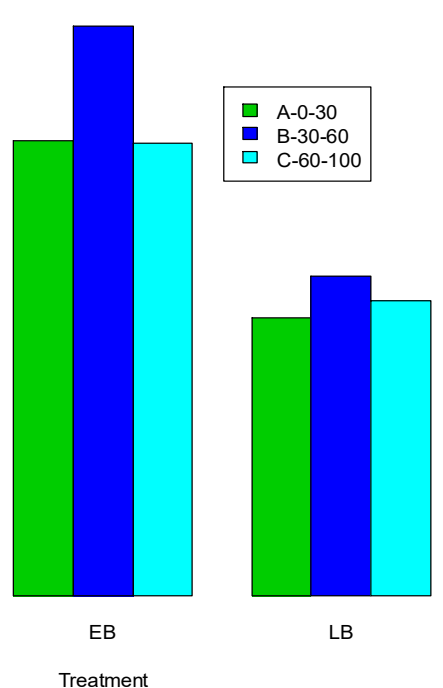

Figure 11: Soil potassium content

Potassium is an essential plant nutrient that plays a role in a wide range of physiological processes, from regulation of the stomata to enzyme activation. Potassium is held in the soil by the cation exchange capacity. The results summarised in figure 1 land table 2 indicates a significant difference in soil potassium content between treatments $(\mathrm{P}<0.05)$. There was more potassium in the early burning treatment. However, the results show no significant $(\mathrm{P}>0.05)$ difference in soil potassium content between horizons. 


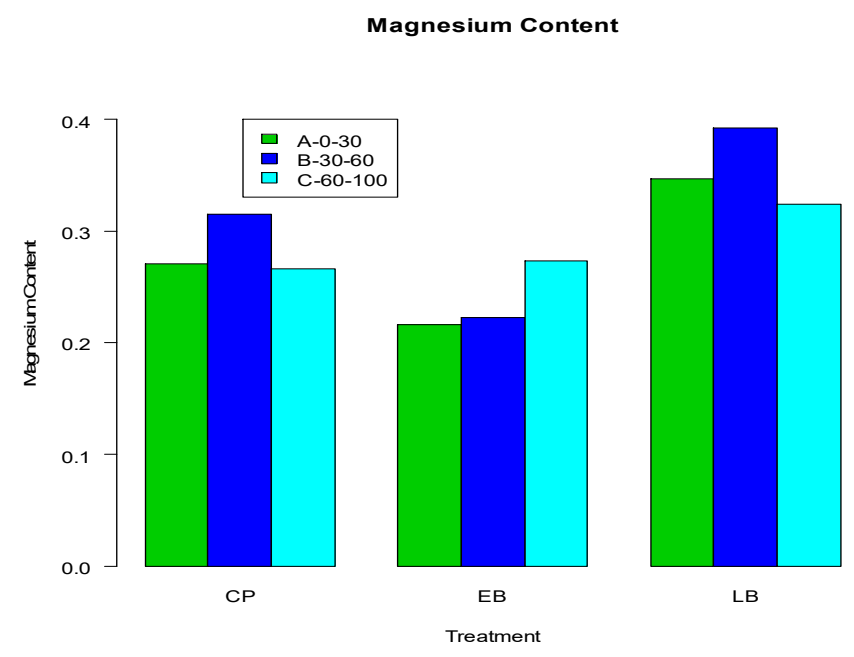

Figure 12: Magnesium in the Soil

Magnesium is essential for healthy plants and is deemed a secondary macronutrient. It is a constituent of chlorophyll so is required for photosynthesis. It is also a component of many plant enzymes and aids in their function. Magnesium helps plants move phosphorus to where it is needed and to use iron. It is important for the uptake of a variety of nutrients and for nitrogen fixation by bacteria associated with legumes. According to the results summarized in figure 12 and table 2 we found no significant $(\mathrm{P}>0.05)$ difference in soil magnesium content between treatments. The results also showed no significant $(\mathrm{P}>0.05)$ difference in soil magnesium content between horizons.

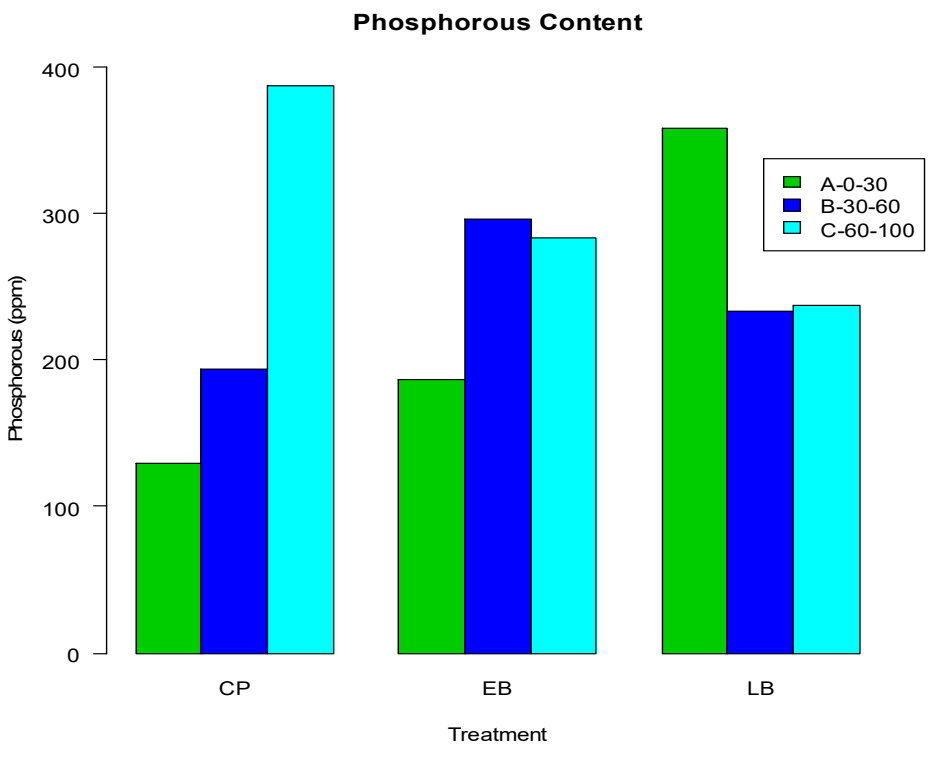

Figure 13: Soil phosphorus content

Phosphorus ( $\mathrm{P}$ ) is essential for all living organisms. Phosphorus plays a role in photosynthesis, respiration, energy storage and transfer, cell division, cell enlargement and several other processes in plants. According to the summarized results in figure 13 and table 2 there is no significant $(\mathrm{P}>0.05)$ difference in soil phosphorous content between treatments. The results also showed no significant $(\mathrm{P}>0.05)$ difference in soil phosphorous content between horizons.

\section{Discussion}

\section{Soil bulky density}

There was no significant $(\mathrm{P}>0.05)$ difference in soil bulky density between treatments as the variations in the bulk density between the soils of the different quadrants, were all falling in the range of $1.48-1.53 \mathrm{~g} / \mathrm{cm}^{3}$ which means these soils are best suited to support plant growth or even to allow for root penetration. The bulk density is important because it reflects the soil's ability to function for structural support, water and solute movement, and soil aeration (Vieilledent et. al. 2012). However, there was a significant difference in soil bulky density between 
horizons $(\mathrm{P}<0.05)$. There was more soil bulky density in the first horizon of $0-30 \mathrm{~cm}$, due to the accumualtion of organic matter which may have increased the bulk density of the soil. Other factors such as the presence of microorganisms that burrow the soil to allow for aeration can also contribute to increasing the number of air spaces and breaking soil clogs.

\section{Soil pH}

There was no significant $(\mathrm{P}>0.05)$ difference in soil $\mathrm{pH}$ between treatments and horizons. Soils become acidic when basic elements such as calcium, magnesium, sodium and potassium held by soil colloids are replaced by hydrogen ions. Soils formed under conditions of high annual rainfall are more acidic than soils formed under more arid conditions. Thus, most wet miombo soils are inherently more acidic than soils of the dry miombo. Differences between treatments were small throughout. This explains why there is no significant $(\mathrm{P}>0.05)$ difference in soil $\mathrm{pH}$ between treatments and horizons.

\section{Soil electrical conductivity}

The soil electrical conductivity varies depending on the amount of moisture held by soil particles. Sands have a low soil electrical conductivity, silts have a medium soil electrical conductivity and clays have a high soil electrical conductivity. Somewhat similarly to our results at site B5-UB, in western Ethiopia, there was a significant difference in soil electrical conductivity between treatments as fires in burned wooded grasslands led to increases in soil electrical conductivity. However, there was no significant difference in soil electrical conductivity between horizons. Other studies have found significant differences in soil electrical conductivity between horizons following fire (e.g. Knicker et al. 2005; Miesel et al. 2012). Most of the variation observed within treatments over time was due to seasonal changes.

\section{Soil moisture content}

Results show no significant $(\mathrm{P}>0.05)$ difference in moisture content between treatments. However, the results show a significant difference in moisture content between horizons $(\mathrm{P}<0.05)$. There was more moisture content in the first horizon $(0-30 \mathrm{~cm})$. This could be attributed to type of soil. A saturated coarse, sandy soil hold far less water than a saturated heavy silty clay. Although significant differences in soil water content were detected between horizons, differences were not large and patterns were not consistent over (Fig. 3 and Tables 1 and 2). Larger differences in soil water content were due to seasonal changes.

Sand has large particles which take up a lot of physical space. Also, as sand particles do not bind water, a lot of water drains out of the sand due to gravity before field capacity is reached. For these two reasons, sand has a much lower maximum and minimum water content than a clay soil does. Our results showed that soil water content were higher in the 0-30 cm horizon (Fig. 6). This difference, however, disappeared with depth as moisture content decreased with depth. Soil moisture content varied predictably with changes in rainfall and soil moisture content declined slightly during the dry season. Although it is hypothesized that the increased soil moisture, temperatures, and litter increases nutrient availability (Bazzaz, 1980), conclusive evidence to suggest this is true has not been reported (Luizao et al., 1998; Vitousek and Denslow, 1986).

\section{Total porosity}

The air and water in the soil exist in the pore space, thus when the soil is saturated with water $100 \%$ of the pores are filled with water, thus the total pore space equals the volume of water in a measured volume of soil. If the soil is allowed to drain freely until all the water flows out due to the pull of gravity the macro pores will be empty. Micro porosity (capillary porosity) retains the water required for plant growth. It also becomes filled with air as the plant extracts the water from these fine pores. The water in these pores is not lost by the forces of gravity. However, the smaller the pores, the greater the difficulty the plant experiences in extracting the water. Compaction results in a reduction in the number, size and continuity of the soil pores. The more moist a soil the more easily it can be compacted because the water acts as a lubricant allowing the particles to move into closer arrangements. The results of this study show no significant $(\mathrm{P}>0.05)$ difference in total porosity between treatments. However, the results show significant difference in total porosity between horizons $(\mathrm{P}<0.05)$. There was more total porosity in the first horizon in all treatments. One of the attributes to this variation in total porosity between horizons is due to soil depth. These results are consistent with findings from other seasonally dry tropical forests (Borchert 1994a)

\section{Total carbon}

Soil carbon is lower on plots subjected to fires, but the effect of different fire regimes is similar in soil horizons (Bird et al. 2000). Evidence from Bird et al. (2000) suggests that soil carbon stocks are higher beneath trees than in adjacent open areas of woodland, which argues for the importance of carbon inputs from trees. Siregar, (2011) and Ryan et al. (2010) reported a positive relationship between soil depth and amount of soil carbon content in clay soil. However, this relationship is inversely related in sandy soil. Results of this study reveals that aboveground pool is most in biomass carbon storage followed by below-ground pool. Litter biomass is third, with grass being least in biomass. This finding is similar to Malimbwi et al. (1994) in his study 'estimation of biomass and volume in miombo woodland at Kitulangalo forest reserve in Tanzania' who reported that $80 \%$ of biomass was found in aboveground parts.

The differences in total carbon in this study, however, indicates that many other factors influence this 
relationship at larger scale as indicated in (fig 8) which shows a significant $(\mathrm{P}<0.05)$ difference in total carbon between treatments. There was more total carbon in complete fire protected treatment. However, the results show no significant $(\mathrm{P}>0.05)$ difference in total carbon between horizons. From the results there is a clear indication that the soil carbon in the soils is significantly high in the complete fire protected treatment. This could be attributed to to undisturbed soils and thus accumulation of carbon over time. Therefore this study is consistent with other studies done by Dai, 2006. However variations that occurred between horizons can not be ignored

Soil carbon is usually reduced by heavy human activity on the soils, the use of fire, is an example because it removes soil cover and leads to immediate and continuing losses of soil organic carbon. The soils in complete fire protected treatment have sufficient ground cover hence the large amounts of organic matter, because the soil cover promotes biological activity and helps protect the soil from wind, rain and extreme temperatures. Soils are also very good carbon sinks, hence the ability of these soils to store large amounts of carbon makes them very good carbon sinks, because by storing large amounts of carbon also help reduce on global warming. This variation could be due to environmental factors and/or historical site disturbance such as fire. These results are consistent with findings from other miombol forests (Chidumayo, 2002). It was also noted that Soil carbon declined logarithmically with depth. This is similar to what was reported by Ribeiro et al. (2008) and Pearson et al. (2005) that the first $30 \mathrm{~cm}$ of soil harbour greater amount of soil carbon. Soil condition is a major attribute to this observed variation. However in contrast to this study, Sarah et al. (2004) in her study of miombo woodlands region of SouthCentral Africa reported that $50-80 \%$ carbon stock is found in the top $1.5 \mathrm{~m}$ belowground. Differences in SOC values could be due to variation in temperature and rainfall that tend to lower rates of soil organic matter decomposition.

\section{Soil nitrogen content}

Plants require more nitrogen $(\mathrm{N})$ than any other nutrient but only a small portion of the nitrogen in soil is available to plants; $98 \%$ of the nitrogen in soil is in organic forms. Most forms of organic nitrogen cannot be taken up by plants, with the exception of some small organic molecules. Macronutrients such as phosphorus, calcium and other exchangeable cations have also been investigated (Radwanski \& Wickens 1967; Tiedemann \& Klemmedson 1973; Kellmann 1979; Belsky et al. 1989). All studies which measured carbon, nitrogen and phosphorus revealed a consistent horizontal pattern in the top soil. The content of these elements declines gradually as a function of the distance from the trunk, and is significantly lower in the open ground than in sub-canopy soil.

In contrast, plants can readily take up mineral forms of nitrogen, including nitrate and ammonia. However, mineral nitrogen in soil accounts for only $2 \%$ of the nitrogen in soil. Soil microorganisms convert organic forms of nitrogen to mineral forms when they decompose organic matter and fresh plant residues. Studies have noted that soil inorganic N increases as fire intensity increases from low to moderate levels (Dunn and DeBano, 1977; Giovannini et al., 1990; Kutiel et al., 1990; McMurtrie and Dewar, 1997; Rice, 1993; Weston and Attiwill, 1996). As shown in figure 9 and table 2 there is a significant $(\mathrm{P}<0.05)$ difference between treatments. There was significant $(p<.05)$ difference in soil nitrogen content between treatments but no significant $(p>.05)$ difference in soil nitrogen content between horizons. There was more nitrogen in third horizon $(60-100 \mathrm{~cm})$ of the complete fire protected treatment. Variation in soil nitrogen contents is due to higher litter fall accumulation on complete fire protected treatment than burnt treatments. Matson et al. (1987) attributed increases in net nitrogen mineralization to microbial death following slash and burn on volcanic soils in Costa Rica. Increased NO3 --N concentrations were likely caused by increased nitrification rates following fires. Environmental factors too such as seasonal temperatures and rainfall had an effect on litter biomass.

\section{Soil calcium content}

All soils contain calcium in the form of cations (positively charged ions, $\mathrm{Ca}++$ that attach to the soil clay and organic matter; these are also the forms taken up by plants. The relative proportion of this element, as well as the total amount in the soil, depends mainly on the soil parent material. In miombo woodlands soils, the levels of calcium is typically high and deficiencies are rare.

The results in figure 10 and table 2 show a significant $(\mathrm{P}<0.05)$ difference in soil calcium content between treatments. There was more calcium in the late burning treatment. However, the results show no significant $(\mathrm{P}>$ $0.05)$ difference in soil calcium content between horizons. The only difference we detected was an increase in calcium in the late burning treatment. We do believe the difference was a result of fire but other factors like temperature and intensity of fire could have contributed in affecting soil calcium content. It is unlikely that fire affected calcium in deep soil layers without causing any impact on surface and shallow soil layers in the late burning treatment. This study also analysed soil calcium at various depth and revealed that top $0-30 \mathrm{~cm}$ as expected contained more calcium content than deeper layers. Nevertheless there was no significant difference in soil calcium content between horizons. This could be attributed to the high-intensity fires which significantly increased Ca concentrations in the late burning treatment. The large amount of ash deposited following high intensity fires was likely the major contributor of increased soil calcium.

\section{Soil potassium content}

Potassium can move more freely in the soil solution between the plants and the soil surfaces. As temperature 
decreases, it is harder for plants to take up potassium. Furthermore, old soils that are very weathered lose their mineral form of potassium and can no longer supply the soil solution with this nutrient. Plants will take up excess potassium if the soil allows, even if the plant does not need it. Potassium very seldom leaches from the soil. It is most abundant in its mineral form, and available forms are most often taken up by plants promptly. The results summarised in figure 11 and table 2 indicates a significant difference in soil potassium content between treatments $(P<0.05)$. There was more potassium in the early burning treatment. However, the results show no significant $(P>0.05)$ difference in soil potassium content between horizons. We believe that combustion of soil potassium begins at 200 to $2508^{\circ} \mathrm{C}$, with complete combustion at, $4608^{\circ} \mathrm{C}$ (Giovannini et al. 1988). Also meta-analyses by Nave et al. (2011), Wan et al. (2001), Johnson and Curtis (2001) and Boerner et al. (2009) found that prescribed fire did not have significant overall effects on either mineral SOC or P, because prescribed fires tend to be implemented under fairly low fuel loads and weather conditions (Nave et al. 2011). Therefore, it is inferred that the burned mineral soils never experienced temperatures high enough for oxidation.

\section{Soil magnesium content}

The availability of magnesium in the soil is affected by: $\mathrm{pH}$ - low soil $\mathrm{pH}$ reduces the availability of magnesium, high $\mathrm{pH}$ increases it. Additionally, excess manganese decreases magnesium uptake. Soils that have high organic matter and clay maintain higher levels of magnesium and such soils absorb magnesium easily and prevent it from leaching. However, if the soil contains little magnesium, it becomes harder for plants to take it up. Low soil temperature reduces magnesium uptake. Magnesium deficiency is most likely to occur in plants grown in acid and/or cold soil. The presence of excess levels of some other nutrients will also increase the chance of magnesium deficiency. The results obtained in this study are also consistent with the few studies done by Garcia-Mendez et al., 1991; Smith et al., 1998). The results found no significant $(P>0.05)$ difference in soil magnesium content between treatments and horizons. The plausible explanation could have arisen due to environmental factors such as altitude or topography.

\section{Soil phosphorus}

Phosphorus is essential for the general health and vigour of all plants. Some specific growth factors that have been associated with phosphorus are: stimulated root development, improved flower formation and seed production, increased resistance to plant diseases and supports development throughout the entire life cycle (Smith et al., 1998). Furthermore, phosphorus is highly mobile in plants, and when deficient, it may be translocated from old plant tissue to young, actively growing areas. Consequently, early vegetative responses to phosphorus are often observed. As a plant matures, phosphorus is translocated into the fruiting areas of the plant, where high-energy requirements are needed for the formation of seeds and fruit.

The total phosphorus content of most surface soils is low, averaging only $0.6 \%$ phosphorus. This compares to an average soil content of $0.14 \%$ nitrogen and $0.83 \%$ potassium. The phosphorus content of soils is quite variable, ranging from less than $0.04 \%$ in the sandy soils. The factors that influence the content of soil phosphorus are as follows: type of parent material from which the soil is derived, degree of weathering and erosion and climatic conditions.

Soil phosphorus is classified into two broad groups, organic and inorganic. Organic phosphorus is found in plant residues, manures and microbial tissues. Soils low in organic matter may contain only $3 \%$ of their total phosphorus in the organic form, but high-organic-matter soils may contain $50 \%$ or more of their total phosphorus content in the organic form. Inorganic forms of soil phosphorus consist of apatite (the original source of all phosphorus), complexes of iron and aluminum phosphates, and phosphorus absorbed onto clay particles. The solubility of these phosphorus compounds as well as organic phosphorus is extremely low, and only very small amounts of soil phosphorus are in solution at any one time. Most soils contain less than a pound per acre of soluble phosphorus, with some soils containing considerably less. Soluble phosphorus, either from fertilizer or natural weathering, reacts with clay, iron and aluminum compounds in the soil, or is converted readily to less available forms by the process of phosphorus fixation. As a result, little soil phosphorus is lost by leaching. This fixed, residual phosphorus remains in the rooting zone and becomes slowly available to succeeding plants.

Precipitation of phosphorus as slightly soluble calcium phosphates occurs in calcareous soils with $\mathrm{pH}$ values around 8.0. Under acid conditions, phosphorus is precipitated as $\mathrm{Fe}$ or Al phosphates of low solubility. Maximum availability of phosphorus generally occurs in a $\mathrm{pH}$ range of 6.0 to 7.0. This is one of the beneficial effects of liming acid soils. Maintaining a soil $\mathrm{pH}$ in this range also favors the presence of H2PO4- ions, which are more readily absorbed by the plant than HPO4+ ions, which occur at $\mathrm{pH}$ values above 7.0. The absence of organic phosphorus in the soil after a fire, coupled with a lack of new organic matter causes a decrease in available phosphorus due to leaching (Duran, 2008).

Contrary to our hypotheses, our results indicate that despite differences in fire regimes soil phosphorus contents were not significantly different between burned and unburned treatments across sites. This observation agrees with the few studies of nutrient cycling conducted in tropical dry forests which have shown that fire management did not affect soil phosphorus contents. Our results are in line with other studies indicating no effect or little effect of fire on mineral phosphorus pools (e.g. Kolka et al.2014; Maynard et al. 2014). 


\section{Conclusions}

Fire affects nutrient cycling and the physical, chemical, and biological properties of soils. Combustion of litter and soil organic matter (OM) increases the availability of some nutrients, although others are volatilized (for example, N, P, S). Late burning fires may have detrimental effects on soil physical properties by consuming soil organic matter. Since soil organic matter holds sand, silt, and clay particles into aggregates. Thus a loss of soil organic matter results in a loss of soil structure. By altering soil structure, severe fires can increase soil bulk density, and reduce soil porosity, mostly through the loss of macropores $(>0.6 \mathrm{~mm}$ diameter). Soil porosity can also be reduced by the loss of soil invertebrates that channel in the soil. The concentration of potassium, calcium, and magnesium ions in the soil can increase or be unaffected by fires whereas nitrogen and carbon often decrease. Although the relationship between fire and soil nutrients is complex because of the interactions among many factors, fire intensity is usually the most critical factor affecting nutrient dynamics, with greater nutrient losses occurring with late burning fires as a result of higher fire intensity.

Fire intensity both directly and indirectly impacts many of the mechanisms that affect nutrient pools and cycling. Fire temperature directly determines the amounts and kinds of nutrients that will be volatilized. $\mathrm{N}$ and $\mathrm{S}$ in these pools are particularly sensitive to fires, and tend to diminish when organic soil horizons are consumed regardless of fire intensity, but mineral $\mathrm{N}$ concentrations tend to increase and become more available in the soil surface after burning. Pools of $\mathrm{P}, \mathrm{K}, \mathrm{Mn}, \mathrm{Mg}$, and $\mathrm{Ca}$ are generally not as likely to be impacted by early burning fires with low intensity fires, but can be lost after high intensity.

Fire generally creates favorable conditions for nitrification by raising $\mathrm{pH}$ values and base saturation. Finally soil bulk density, soil moisture content, and soil electrical conductivity were not significantly different from those in unburned treatment. Again, this pattern may reflect the influence of organic matter on soil physical characteristics. Soil bulky density was greater in the complete protected than burnt plots. Other than the observed differences in total soil carbon, soil organic matter, soil electrical conductivity, total porosity, nitrogen, calcium, potassium and magnesium between treatments this did not significantly change the soil chemical or physical properties in all treatments.

\section{Author contribution}

The results of this study will contribute in filling knowledge gap existing in areas of long term influence of fire on soil properties.

\section{Acknowledgements}

The authors wish to thank Mr Felix Chileshe for assisting with field and laboratory work. We are also grateful to Professor Chidumayo Emmaniuel for his valuable comments on the research design.

\section{Conflict of interest}

Authors declare no conflict of interest.

\section{References}

Araki, S. 1993. Effect on soil organic matter and soil fertility of the chitemene slash-and-burn practice used in northern Zambia. In: Mulongoy, K. and Merckx, R. (eds) Soil organic matter dynamics and sustainability of tropical agriculture, 367-375. IITA/K.U., Leuven, Belgium.

Archibald S, Staver AC, Levin SA. 2012. Evolution of human-driven fire regimes in Africa. Proceedings of the National Academy of Sciences of the United States of America 109, 847-852. doi:10.1073/PNAS.

Bazzaz F A and Pickett S T. 1980. Physiological ecology of tropical succession: a comparative review. Annu. Rev. Ecol. Sys. 11, 287-310.

Belsky, A. J., Amundson, R. G., Duxbury, J. M., Riha, S. J., Ali, A. R. \& Mwonga, S. M. 1989. The effects of trees on their physical, chemical, and biological environment in a semi-arid savanna in Kenya. J. Appl. Ecol. 26: $1005-1024$

Bird, M. I., E. M. Veenendaal, C. Moyo, J. Lloyd, and P. Frost. 2000. Effect of fire and soil texture on soil carbon in a sub-humid savanna (Matopos, Zimbabwe). Geoderma 94 (1): 71-90

Boerner REC, Hart S, Huang J. 2009. Impacts of fire and fire surrogate treatments. Ecological Applications 19, 338-358. doi:10.1890/07-1767.1

Borchert, R., 1994a. Water status and development of tropical trees during seasonal drought. Trees 8, 115-125.

Bowman, D. M., Balch, J. K., Artaxo, P., Bond, W. J., Carlson, J. M., Cochrane, M. A., Harrison, S. P. 2009. Fire in the Earth System. Science, 324(5926), 481-484.

Bremner JM, Mulvaney CS. 1982. Nitrogen - total. In 'Methods of soil analysis, Part 2. Chemical and microbiological properties', 2nd edn. (Eds AL Page, RH Miller, DR Keeney) pp. 595-624. (Soil Science Society of America, Inc. and American Society of Agronomy, Inc.: Madison, WI)

Certini, G. 2005. Effects of fire on properties of forest soils: a review. Oecologica 143: pp 1-10. 
Chidumayo, E. N. 1988. 'A re-assessment of effects of fire on miombo regeneration in the Zambian Copperbelt.' Journal of Tropical Ecology 4:361-372.

Chidumayo, E.N. 2002. Climate and Phenology of Savannah Vegetation in Southern Africa. Journal of vegetation Science 12: 347-433.

Chidumayo, E.N. and Gumbo, D.J. 2010. The Dry Forests and Woodlands of Africa. Earth Scan, London.

Dai WH \& Huang Y. 2006. Relation of soil organic matter concentration to climate and altitude in zonal soils of China. Catena 65(1):87-94

Dunn P H and DeBano L F. 1977. Fire's effect on biological and chemical properties of chaparral soils. General Technical Report WO-3, USDA Forest Service.

Duran J., Rodriguez A., Fernandez-Palacios J.,Gallardo A. 2008. Changes in soil N and P availability in a Pinus canariensis fire chronosequence. Forest Ecology and Management Journal. 256, 384-387.

Garcia-Mendez G, Maas J M, Matson P A and Vitousek P M. 1991. Nitrogen transformations and nitrous oxide flux in a tropical deciduous forest in Mexico. Oecologia 88, 362-366.

Giovannini G, Lucchesi S, Giachetti M. 1988. Effects of heating on some physical and chemical parameters related to soil aggregation and erodibility. Soil Science 146, 255-261. doi:10.1097/00010694- 198810000-00006

Giovannini G, Lucchesi S and Giachetti M. 1990. Beneficial and detrimental effects of heating on soil quality. In Fire and Ecosys 129 tem Dynamics: Mediterranean and Northern Perspective. Eds.J G Goldammer and M J Jenkins. pp 95-102. SPB Academic Publishing, Hague, The Netherlands

Grossman RB, Reinsch TG. 2002. Bulk density and linear extensibility. In 'Methods of soil analysis, Part. 4. Physical methods'. (Eds JH Dane, GC Topp) pp. 201-254. (Soil Science Society of America, Inc. and American Society of Agronomy, Inc.: Madison, WI

Hoffmann, W. A., and O. T. Solbrig. 2003. The role of topkill in the differential response of savanna woody species to fire. Forest Ecology and Management 180:273-286.

Jobbágy, E. G., \& Jackson, R. B. 2000. The Vertical Distribution of Soil Organic Carbon and Its Relation to Climate and Vegetation. Ecological Applications, 10(2), 423-436.

Johnson DW, Curtis PS. 2001. Effects of forest management on soil C and N storage: meta-analysis. Forest Ecology and Management 140,227-238. doi:10.1016/S0378-1127(00)00282-6

Kaye JP, Romanya' J, VallejoVR. 2010. Plant and soil carbon accumulation following fire in Mediterranean woodlands in Spain. Oecologia 164,533-543. doi:10.1007/S00442-010-1659-4

Kellmann, M. 1979. Soil enrichment by neotropical savanna trees. J. Ecol. 67: 565-577.

Kolka R, Sturtevant B, Townsend P, Miesel J, Wolter P, Fraver S, DeSutter T. 2014. Post-fire comparisons of forest floor and soil carbon, nitrogen, and mercury pools with fire severity indices. Soil Science Society of America Journal 78, S58-S65. doi:10.2136/SSSAJ2013.08.0351NAFSC

Knicker H, Gonza'lez-Vila FJ, Polvillo O, Gonza'lez JA, Almendros G. 2005. Fire induced transformation of Cand $\mathrm{N}$-forms in different organic soil fractions from a Dystric Cambisol under a Mediterranean pine forest (Pinus pinaster). Soil Biology \& Biochemistry 37, 701-718. doi:10.1016/J.SOILBIO.2004.09.008

Kutiel P, Naveh Z and Kutiel H. 1990. The effect of wildfire on soil nutrients and vegetation in aleppo pine forest on Mount Carmel, Israel. In Fire and Ecosystem Dynamics: Mediterranean and Northern Perspective. Eds. J G Goldammer and M J Jenkins. Pp 255-267. SPB Academic Publishing, Hague, The Netherlands.

Malimbwi, R.E., Solberg, B. \& Luoga, E. 1994. Estimation of Biomass and Volume in

Miombo Woodland at Katulangalo Forest Reserve, Tanzania. Journal of tropical Science, 7: 230-242.

Marschner, B., Brodowski, S., Dreves, A., Gleixner, G., Gude, A., Grootes, P. M., Hamer, U., Heim, A., Jandl, G., Ji, R., Kaiser, K., Kalbitz, K., Kramer, C., Leinweber, P., Rethemeyer, J., Schäffer, A., Schmidt, M. W. I., Schwark, L. \& Wiesenberg, G. L. B. 2008. How relevant is recalcitrance for the stabilization of organic matter in soils? Journal of Plant Nutrition and Soil Science, 171: 91-110.

Mann HB, Whitney DR. 1947. On a test of whether one of two random variables is stochastically larger than the other. Annals of Mathematical Statistics 18, 50-60. doi:10.1214/AOMS/1177730491

Matson PA, Vitousek P M, Ewel J J, Mazzarino M J and Robertson G P. 1987. Nitrogen transformations following tropical forest felling and burning on a volcanic soil. Ecology 68, 491-502.

Maynard DG, Pare' D, Thiffault E, Lafleur B, Hogg KE, Kishchuk B. 2014. How do natural disturbances and human activities affect soils and tree nutrition and growth in the Canadian boreal forest? Environmental Review 22, 161-178. doi:10.1139/ER-2013-0057

McMurtrie R E and Dewar R C. 1997. Sustainable forestry: a model of the effects of nitrogen removals in wood harvesting and fire on the nitrogen balance of regrowth eucalypt stands. Aust. J. Ecol.22, 243-255.

Miesel JR, Goebel PC, Corace RG, Hix DM, Kolka R, Palik B, Mladenoff D. 2012. Fire effects on soils in Lake States forests: a compilation of published research to facilitate long-term investigations. Forests 3,1034-1070. doi:10.3390/F3041034

Nave LE, Vance ED, Swanston CW, Curtis PS. 2011. Fire effects on temperate forest soil C and N storage. Ecological Applications 21, 1189-1201. doi:10.1890/10-0660.1 
Nelson DW, Sommers LE. 1996. Total carbon, organic carbon, and organic matter. In 'Methods of soil analysis, Part 3. Chemical methods'. (Eds DL Sparks, AL Page, PA Helmke, RH Loeppert, PN Soluanpour, MA Tabatabai, CT Johnston, ME Sumner) pp. 961-1010. (Soil Science Society of America, Inc. and American Society of Agronomy, Inc.:Madison, WI)

Parton, W., Schimel, D. S., Cole, C., \& Ojima, D. 1987. 'Analysis of Factors Controlling Soil Organic Matter Levels in Great Plains Grasslands.' Soil Science Society of America Journal, 51(5), 1173-1179.

Pearson T, Walker S, \& Brown S. 2005. Sourcebook for Land Use, Land-Use Change and

Forestry Projects. Washington DC: Winrock International and the Bio Carbon Fund of the World Bank.

Radwanski, S. A. \& Wickens, G. E. 1967. The ecology of Acacia albida on mantle soils in Zalingei, Jebel Marra, Sudan. J. Appl. Ecol. 4: 569-579.

Ryan, C. M., and M. Williams. 2011. How does fire intensity and frequency affect miombo woodland tree populations and biomass? Ecol. Appl., doi:10.1890/09-1489.1.

Ribeiro, N. S., H. H. Shugart, and R. Washington-Allen 2008. The effects of fire and elephants on species composition and structure of the Niassa Reserve, northern Mozambique, For. Ecol. Manage.,255(5-6), 16261636.

Ribeiro, NS; Matos, C.N.; Moura, IR; Washington- Allen, RA and Ribeiro, AI. 2013. Monitoring vegetation dynamics and carbon stock density in Miombo woodlands. Carbon Balance and Management 8:11; http://www.cbmjournal.com/content/8/1/11.

Rice S K. 1993. Vegetation establishment in post-fire Adenostoma chaparral in relation to ine-scale pattern in fire intensity and soil nutrients. J. Veg. Sci. 4. 115-124.

Sarah, Walker \& Paul, 2004. The Impact of Land-Use on Soil Carbon in Miombo Woodlands of Malawi. Forest Ecology and Management 203: 345-360.

Schmidt, M. W. I., Torn, M. S., Abiven, S., Dittmar, T., Guggenberger, G., Janssens, I. A., Kleber, M., KögelKnabner, I., Lehmann, J., Manning, D. A. C., Nannipieri, P., Rasse, D. P., Weiner, S. \& E. Trumbore, S. E. 2011. Persistence of soil organic matter as an ecosystem property. Nature, 478: 49-56.

Shapiro SS, Wilk MB. 1965. An analysis of variance test for normality (complete samples). Biometrika 52, 591611. doi:10.1093/BIOMET/52. 3-4.591

Siregar, C.A. 2011. Develop Forest Carbon Standard and Carbon Accounting System for Small-Scale Plantation Based on Local Experiences. Indonesia's Ministry of Forestry - International Tropical Timber Organisation.

Smith C K, Gholz H L and De Assis Oliveira F. 1998 .Soil nitrogen dynamics and plant-induced soil changes under plantations and primary forest in lowland Amazonia, Brazil. Plant Soil 200, 193-204. Sokal and Rolf 1981 Biometry, 2nd Edition. Freeman, New York.

Tiedemann, A. R. \& Klemmedson, J. 0. 1973. Effect of Mesquite on physical and chemical properties of the soil. J. Range Manage. 26: 27-29.

Thévenot, M., Dignac, M.-F. \& Rumpel, C. 2010. Fate of lignins in soils: a review. Soil Biology and Biochemistry, 42: $1200-1211$

Vieilledent G, Vaudry R, Andriamanohisoa SD, Rakotonarivo OS, Randrianasolo HZ, et al. 2012. A universal approach to estimate biomass and carbon stock in tropical forests using generic allometric models. Ecological Applications 22:

Vitousek PM, Matson PA. 1988 .Nitrogen transformations in a range of tropical forest soils. Soil Biology and Biochemistry, 20, 361-367.

Wan S, Hui D, Luo Y. 2001. Fire effects on nitrogen pools and dynamics in terrestrial ecosystems: a meta-analysis. Ecological Applications 11, 1349-1365. doi:10.1890/1051-0761(2001)011[1349:FEONPA] 2.0.CO;2

Walkley A, Black I A. 1934 An examination of the Degtjareff method for determining soil organic matter, and a proposed modification of the chromic acid titration method. Soil Science 37, 29-38. doi:10.1097/00010694193401000-00003

Weston C J and Attiwill P M. 1996. Clear felling and burning effects on nitrogen mineralization and leaching in soil of old-age Eucalyptus regnans forests. For. Ecol. Manage. 89, 13-24.

Zar, J.H., 2000. Biostatistical Analysis. Fourth Edition, Prentice Hall, Upper Saddle River, New Jersey, 662 pp.

\section{Figure legends}

